Boise State University

ScholarWorks

University Author Recognition Bibliography:

2020

University Author Recognition Bibliographies

$11-2020$

Environmental Responsibility and Rohingya Refugees: Potential

Grounds for Justice

Leonard Hammer

University of Arizona

Saleh Ahmed

Boise State University

This is an Accepted Manuscript of an Article published in Local Environment on November 2020, available online at https://doi.org/10.1080/13549839.2020.1849078. The content of this document may vary from the final published version. 
This is an author-produced, peer-reviewed version of this article. The final, definitive version of this document can be found online at Local Environment, published by Taylor \& Francis. Copyright restrictions may apply. doi: 10.1080/13549839.2020.1849078

\title{
Environmental Responsibility and Rohingya Refugees: Potential Grounds for Justice
}

\author{
Leonard Hammer \\ The University of Arizona \\ Saleh Ahmed \\ Boise State University
}

\begin{abstract}
In response to extreme violence by Myanmar, over one million Rohingya refugees have flooded into Bangladesh, resulting in massive scale deforestation, land erosion, farmland degradation, and destruction of animal habitat, along with the Rohingya being denied basic environmental protections. Because neither Bangladesh nor the Rohingya are responsible for this environmental calamity, a variety of environmental legal claims can be raised against Myanmar, serving as grounds for proper redress to both the receiving state and the refugees therein. This paper highlights the emergence of environmental law as a basis for finding a sending state liable for the environmental impact and damage that it has caused to the receiving state and refugees due to the creation of a refugee crisis.
\end{abstract}

Keywords: Rohingya; Bangladesh; Myanmar; refugees; environmental damage; environmental responsibility

\section{Introduction}

The number of forcibly displaced people has grown considerably in the past decade. Globally, it is now 79.5 million, which is the highest number since the World War II. Among those, $40 \%$ are children, $85 \%$ are hosted in the developing world, and 73\% are hosted in neighboring country (UNHCR 2020). These displacements and associated humanitarian crises can arise from a variety of reasons, sometimes due to factors that might be beyond the control of a single state. Yet, the majority of reasons for refugee creation has largely been strife in a particular country due to armed violence, discrimination, or persecution, as evidenced by some of the most recent and severe refugee crises witnessed in Syria, Bangladesh, and Eritrea (Freedman 2019).

What is interesting when thinking about refugee protection is the fact that the bulk of the responsibility for the displaced population falls on receiving states, civil society actors, and international organizations to address refugee crises and bear the expenditures that are entailed as a result (Akhavan and Bergsmo 1989). The 'sending' or 'causing' state so to speak essentially is absolved from any connection to the crises they caused. An important issue then is how to incorporate the sending state into the mix and hold them responsible for generating massive costs to the receiving state as well as causing misery for large groups of forcibly displaced people.

The approach that will be considered in this paper is to elaborate upon the impact that a large refugee population maintains on the environment in the receiving state as a result of the actions of the sending state, a notion not previously considered when accounting for a sending state's international legal responsibility. This paper focuses specifically on the forcibly displaced Rohingya population from Myanmar as the response to social, cultural, and ethnic violence against them and the subsequent environmental damages that resulted in the receiving state Bangladesh as a telling example of the means for applying environmental culpability. The environmental disruption in southeast Bangladesh is directly linked to the social, economic, and political chaos in Myanmar.

The reasons for turning to environmental damage as an avenue to bring to bear the international responsibility of a sending state is because environmental damage is both quantifiable, even if subject to a variety of evaluative approaches, (Cittadino 2019), and unfortunately largely unavoidable, as witnessed in recent massive forciblydisplaced refugee crisis, such as found in Bangladesh or states surrounding Syria. Yet, environmental damage is somewhat oddly unaccounted for when considering the damages caused by massive refugee movements. Further, present refugee laws provide no specific actions to hold the sending state accountable for its generating chaos and 
This is an author-produced, peer-reviewed version of this article. The final, definitive version of this document can be found online at Local Environment, published by Taylor \& Francis. Copyright restrictions may apply. doi: 10.1080/13549839.2020.1849078

environmental damage. Indeed, current attempts at justice are largely ineffectual ex-post efforts, such as making a request for an indictment by the International Criminal Court (ICC), that do not address the ills caused by the sending state nor alleviate the damages caused to the refugees and the receiving state.

Further, what is largely overlooked are the environmental impacts that a receiving state has to endure as the result of an influx of people (World Bank 2011). Indeed, environmental impacts are rather severe and unavoidable in both the short and long term especially when accounting for land shortage, land use issues, impact on surrounding areas in the receiving state, the detrimental effect of a huge influx of people to a small enclosed area, and the capacity of the receiving state to even deliver essential services to the refugee population, such as education, social services, food, water, sanitation (McCue 1993).

Thus, what will be asserted herein is that Myanmar caused a run of displaced people into Bangladesh, leading to major environmental damage, which included massive scale deforestation, land erosion, and destruction of animal habitat. This then opens the door for a variety of environmental claims that can be raised by Bangladesh as well as the Rohingya to make a claim against Myanmar, thereby serving as grounds for redress for the receiving state Bangladesh and forcefully displaced Rohingya population against the sending state. The recent developments in international environmental justice, where scholars investigated environmental justice from a situated and networked context (Vermeylen 2019), open the door for forms of potential recompense to the receiving state on the basis of calculated environmental damages, increases responsibility on the receiving state for attending to the basic needs of the incoming refugees or displaced populations to provide a safe and stable environment, and potentially provided disincentives for sending states to even create conditions of displacement in the future.

More pointedly, this paper highlights the fact that given the emergence of environmental law as a basis for invoking a state's human rights responsibilities, it is conceivable that grounds exist for finding the sending state liable for the environmental impact and damage that it has caused as a result of creating a refugee influx in a receiving state. Environmental quantification is especially poignant for the Rohingya situation in Bangladesh, where environmental destruction is extensive and far-reaching and where Myanmar as the sending state has thus far not borne any form of responsibility, let alone any form of recompense for Bangladesh (as the receiving state) or for the displaced Rohingya population.

\section{State Responsibility}

The key initial challenge with the refugee crisis is of course how to invoke aspects of state responsibility against a state which is the actual cause for a massive refugee event. While this might appear as an odd statement to make, especially in instances where state policy clearly is calling for expulsion or violent action against a specific population group. In reality it is not easy to hold a state liable for the damages it causes as a result of its creation of a refugee influx in another state. Essentially, state responsibility is the notion of holding a state accountable for the consequences of illegal acts (Beyani 1995). The difficulty is that it is "the states" who are involved in the commission of the crimes, thus making it harder to not only enforce the law, but also provide avenues for proper redress. Arguably that could be the partial reason as to why states might prefer issues like genocide and war crimes to be left in the hands of political.

Nevertheless, the emergence of the realization that states actually are responsible in some way for causing large refugee events when emanating from acts of genocide, war crimes, or crimes against humanity, indicates that state responsibility can play a role in dealing with international crimes. Yet, relying on existing international processes to protect refugees usually involves high standards of proof of extreme and serious actions by the sending state. The claim of genocide for example entails a host of proof and evidence regarding intent that is not always that easy to demonstrate. The ICC will only allow for serious violations by state leaders and policy makers if it can be shown that a policy existed to engage in actions like genocide or crimes against humanity, such as a clear and stated policy to expel and deracinate the Rohingya from Myanmar.

Also, there exist surrounding political factors that influence states in utilizing international processes. Consider for example the major push back from Bangladesh in referring to the ICC given hesitation by India in making use of the court and the influence that the latter wields over the former (BDnews24.com 2018). Bangladesh in essence is hesitant to be involved in a suit for its own political reasons and state interests that are implicated in challenging Myanmar in an international forum (Curfman 2018). Further, the process at the ICC, which started an investigation against Myanmar in November, 2019, will be quite lengthy and not really result in any redress as such for the displaced population or for Bangladesh. Another problem of note with the ICC is that targeting individual authors of crimes, 
This is an author-produced, peer-reviewed version of this article. The final, definitive version of this document can be found online at Local Environment, published by Taylor \& Francis. Copyright restrictions may apply. doi: 10.1080/13549839.2020.1849078

even high-ranking officials, as responses to state criminality is only a partial solution. While an ICC indictment might create a deterrence in the future, an ICC trial does not remove the need for addressing existing ongoing issues such as maltreatment of a specific minority group or rampant discrimination (Nollkaemper 2010) Thus, calling out state officials or even indicting and eventually imprisoning them does not offer a practical solution for refugees, the receiving state, or relevant international and regional actors who bear the cost of the sending state's illegal actions.

The same reasons can be said for reference to the International Court of Justice (ICJ) when invoking for example the Convention to Eliminate Racial Discrimination (CERD). Assertions under CERD in the case of the Rohingya, while seemingly viable given Myanmar's deliberate actions against a specific ethnic group, might not yield beneficial results nor any form of meaningful compensation to the receiving state or the Rohingya (Arnpriester and Bingham 2019; Andjelkovic 2019). Another ICJ avenue that uses the Genocide Convention might be a commendable step but also will not lead to much if any redress. Claims against Myanmar have been raised before the ICJ, such as a recent action by the West African nation of Gambia in its November, 2019 filing against Myanmar (Bhuiyan 2019; Barron 2020; Bowcott 2019). The case has been described as “.... a landmark step to stop further atrocities against one of the world's most prosecuted people." (Singh 2020). While arguments were presented and discussed before the ICJ in December, 2019 (ICJ 2020), the outcome will not spell practical relief other than some sense of moral justice for those directly impacted by the events.

Similarly, actions raised in the domestic courts on the basis of universal jurisdiction making the claim that a genocide occurred in Myanmar against the Rohingya similarly might be a bright spot for justice, but will not result in any meaningful compensation for those injured (Kamruzzaman 2020). Thus, although state responsibility can capture the wider gamut of those responsible for crimes committed, it still is beset by a weak framework of enforcement and not necessarily directed towards those most impacted by heinous actions like genocide, which lead to massive refugee events.

One approach to address such injustice within the rubric of state responsibility however can be to examine alternative avenues for damage incurred pursuant to claims that present stronger grounds for action against a state (Nollkaemper 2010). That is, responsibility can create possibilities for remedial actions for example by relying on the invocation of law by the injured themselves or by interested or impacted states. There have been some discussions and initial inroads into seeking grounds for finding a sending state liable for refugee problems, when the sending state is the actual cause for the refugee movement (Akhavan and Bergsmo 1989; Howland 2007; Lee 1986; Ahmad 2009). The basis for such forms of state responsibility in the context of refugees includes the overall rights and duties of states, the exercise of territorial jurisdiction in a manner which interferes with the exercise by other states of their respective jurisdiction (given that a mass influx of people are entering another state's sovereign territory), the sovereign equality of states, unlawful deprivation of nationality, and a quasi-contractual relationship which is involved in the protection of refugees (Lee 1993; Beyani 1995). Thus, Bangladesh might have grounds for example to challenge Myanmar as violating the International Covenant on Economic Social and Cultural Rights for failing to uphold its obligations towards the Rohingya and essentially moving the responsibility under the treaty on to Bangladesh, especially as both states are members of the treaty at least as of 2017 (United Nations Human Rights Office of the High Commissioner 2017).

More to the point, it is worth considering international documents such as the 1992 Cairo Declaration of Principles of International Law on Compensation to Refugees (DPILCR) that provides, at Principle 5, that a state that has committed an 'internationally wrongful act' through the generation of refugees shall be required, as appropriate: (i) to discontinue the act; (ii) to apply remedies provided under the municipal law; (iii) to restore the situation to that which existed prior to the act; (iv) to pay compensation in the event of the impossibility of the restoration of the pre-existing situation; and (v) to provide appropriate guarantees against the repetition or recurrence of the act (Lee 1993). The earlier versions of the 1992 DPILCR had two interesting clauses, such as the Principle 9, which provided that: The imposition of the refugee burden upon a country without its consent is a violation of its territorial sovereignty, including its right to exercise jurisdiction over its own territory and over all persons and things therein. It impinges upon the basic norms governing the rights and duties of States. Principle 10 further provided that: The right of a country of asylum to compensation is based, inter alia, on the economic, social and other burdens that the presence of large numbers of refugees inevitably imposes upon it, at least in the short run. These principles indicate that shifting of a country's own burdens of caring for its citizens to another country without the latter's consent, by means of a refugee movement caused directly or indirectly by the former's actions, creates a quasi-contractual relationship under which the former owes a duty of compensation to the latter. 
This is an author-produced, peer-reviewed version of this article. The final, definitive version of this document can be found online at Local Environment, published by Taylor \& Francis. Copyright restrictions may apply. doi: 10.1080/13549839.2020.1849078

In discussing the lack of compensation available to refugees and the potential for individual entitlement under law when a state creates a refugee situation, Lee (1993) notes the mass expulsion of nationals as a violation giving the right to compensation of the individuals harmed thereby. In furthering this notion, especially for receiving states, Lee (1993) specifically references the need for disincentives against the sending state to prevent mass refugee problems. Upon discussing the grounds for these claims, Lee (1993) refers to the international laws regarding state responsibility, relying interestingly on the Trails Smelter Arbitration of 1938 and 1941. In the Trails Smelter arbitration, the question arose as to whether a state may continue an activity that inflicts legally compensable injury. The United States maintained that "so long as fumigations occur in the State of Washington with such frequency, duration and intensity as to cause injury," the conditions afforded "grounds of complaint on the part of the United States, regardless of the remedial works... and regardless of the effect of those works" (1934 USA Letter from Trails Smelter Arbitration, at 1962-1963). The tribunal found that the U.S. position conformed with the general rules of international law and decided that "the Trail Smelter shall be required to refrain from causing any damage through fumes in the State of Washington" (Trails Smelter Arbitration at 1996) in addition to paying for the actual damages.

These attempts at finding a state responsible under international law are but beginning steps in imposing compensatory justice on a sending state. The challenge is to locate actual causes of action that tend to assist the receiving state and the refugees themselves in receiving enforceable means of compensation for the damages that have been inflicted upon them.

\section{The Rohingya Crisis}

In Myanmar, the Rohingya, as a targeted ethnic group, experienced decades of systematic discrimination that seemingly amounted to "apartheid" given the ongoing violation of their rights, with the repression intensifying in recent years (Amnesty International 2017). Tensions based on socio-ethnic differences between Buddhist and Muslim communities in Myanmar's Rakhine State escalated dramatically in August 2017 (UN 2018), with the presumed catalyst for Myanmar's severe reaction being an attack on Myanmar military and police outposts by the Arakan Rohingya Salvation Army (ARSA) a group of Rohingya militants. The attack resulted in the death of more than seventy people, including twelve security personnel forces (Council on Foreign Relations 2018). In response, the Myanmar military launched a brutal crackdown on Rohingya villages, causing nearly one million people to flee across the border to Bangladesh. This newly arrived Rohingya are predominantly living in Ukhia and Teknaf in the Cox's Bazar district of Bangladesh. The area of recent Rohingya influx is bordered on the north by Ramu and Naikhongchhari, by Arakan state of Myanmar on the east, and by the Bay of Bengal on the south and west. 
This is an author-produced, peer-reviewed version of this article. The final, definitive version of this document can be found online at Local Environment, published by Taylor \& Francis. Copyright restrictions may apply. doi: 10.1080/13549839.2020.1849078



Figure 1. Distribution of Rohingya Population in various camps in southeast Bangladesh

The speed and scale of the Rohingya influx in Bangladesh has resulted critical humanitarian emergency (UNDP Bangladesh and UN WOMEN Bangladesh 2018). The United Nations (UN) describes this atrocity by the Myanmar Army as a "...textbook example of ethnic cleansing" (UN 2017). In Bangladesh, Rohingya populations is facing another level of identity crisis, since they are not yet recognized as refugees, but rather as "Forcibly Displaced Myanmar Nationals (FDMNs)." This status does not give any privilege as refugees in the host country and further hinders their capacity to seek redress or afford Bangladesh some means of reprieve. An additional and not surprising development is the labeling of Rohingya as the other in Bangladesh that will have long-term social consequences as the situation unfolds. Yet, their presence in Bangladesh mandates some form of protection and state provision to ensure that they live a life of dignity, including aspects such as water, sanitation, habitation, and even education.

\section{Local Environmental Impacts}

The Rohingya influx has caused a major impact on local forests and amplified human-wildlife conflict in southeast Bangladesh (UN Environment 2018). Stairs and terraces were cut into the hillsides to make space for temporary Rohingya makeshift dwellings. In the Ukhia, Whykong, and Teknaf forest range in southeast Bangladesh, which is the region that is close to Myanmar-Bangladesh border, a total of 3,713 acres (1,502 ha) have been used for the immediate construction of temporary Rohingya Rohingya makeshift settlements (UNDP Bangladesh and UNWOMEN Bangladesh 2018). Only in the Kutupalong Camp, which is now known as the world's largest refugee camp, 1328 acres of forest land have been encroached. 
This is an author-produced, peer-reviewed version of this article. The final, definitive version of this document can be found online at Local Environment, published by Taylor \& Francis. Copyright restrictions may apply. doi: 10.1080/13549839.2020.1849078

The camps' residents are crowded into hilly areas with almost no facilities, a situation that is increasingly untenable (See Figure 2) (Ahmed 2018; GFDRR 2018).

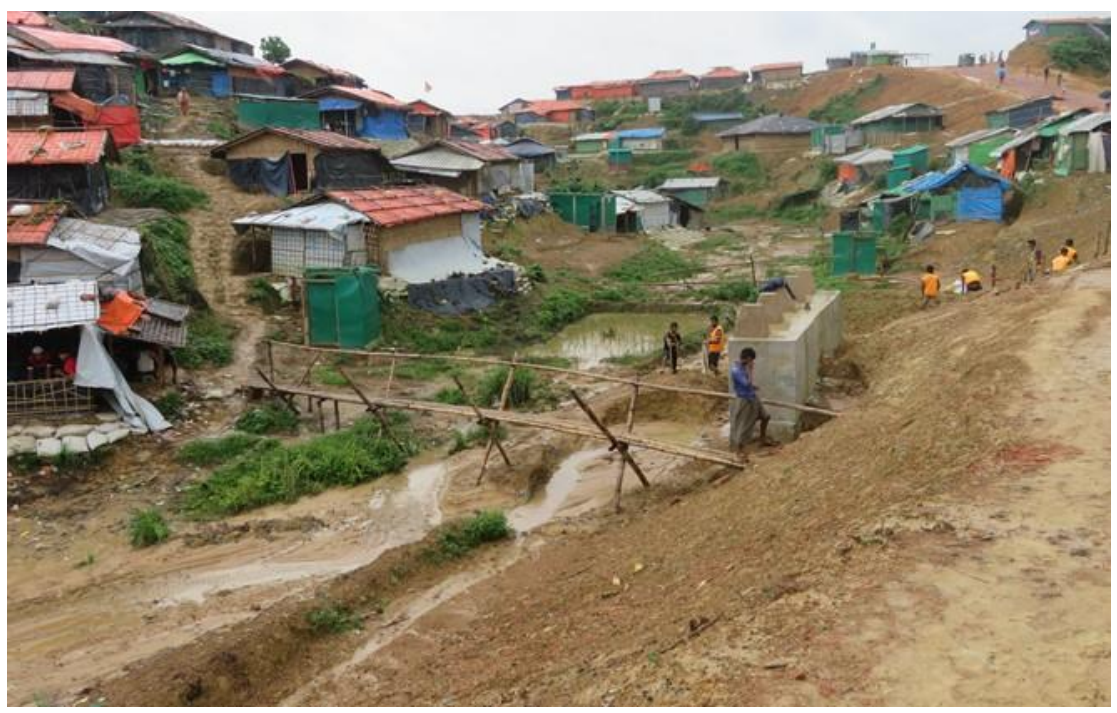

Figure 2. Kutupalong Rohingya Camp (Cox’s Bazar, Bangladesh)

Due to the limitations of space and local geomorphological formations, Rohingya population are forced to live in the hilly terrains, which are highly vulnerable to landslides, and flashfloods. In addition, because of the unpaved muddy slippery roads, it is particularly challenging for Rohingya women, children, and elderly members of the households to walk in these areas. The government of Bangladesh and other development and humanitarian partners are trying to make the makeshift shelters a little more stable and accessible by using sandbags and by making temporary bamboo/wooden bridges.

As an emergency response, most of the support given was based on immediate need, for example, emergency food aid, temporary shelters, and basic health supports (UN 2018). However, there was relatively limited focus on the local environmental impact in both the short and long-term. Sources claim that 400 acres out of 600 acres of local reserve forest were used for constructing the refugee shelters between August 2017 and January 2018. In a one-year period between December 2016 and December 2017, the Kutupalong-Balukhali Rohingya camp, which is known now to be the world's largest refugee camp, extended from 146 hectares to 1365 acres (Hassan et al. 2018).

In a press conference release on June $4^{\text {th }}, 2018$, Barkat Ullah Maruf mentioned that daily 2,250 tons of firewood was being burnt only for cooking in various camps in Ukhia and Teknaf. Because of the growing demands for fuel consumptions, some people from the local host communities also engaged in cutting forest resources and sell those to Rohingya (Maruf 2018) (See Figure 3). 
This is an author-produced, peer-reviewed version of this article. The final, definitive version of this document can be found online at Local Environment, published by Taylor \& Francis. Copyright restrictions may apply. doi: 10.1080/13549839.2020.1849078

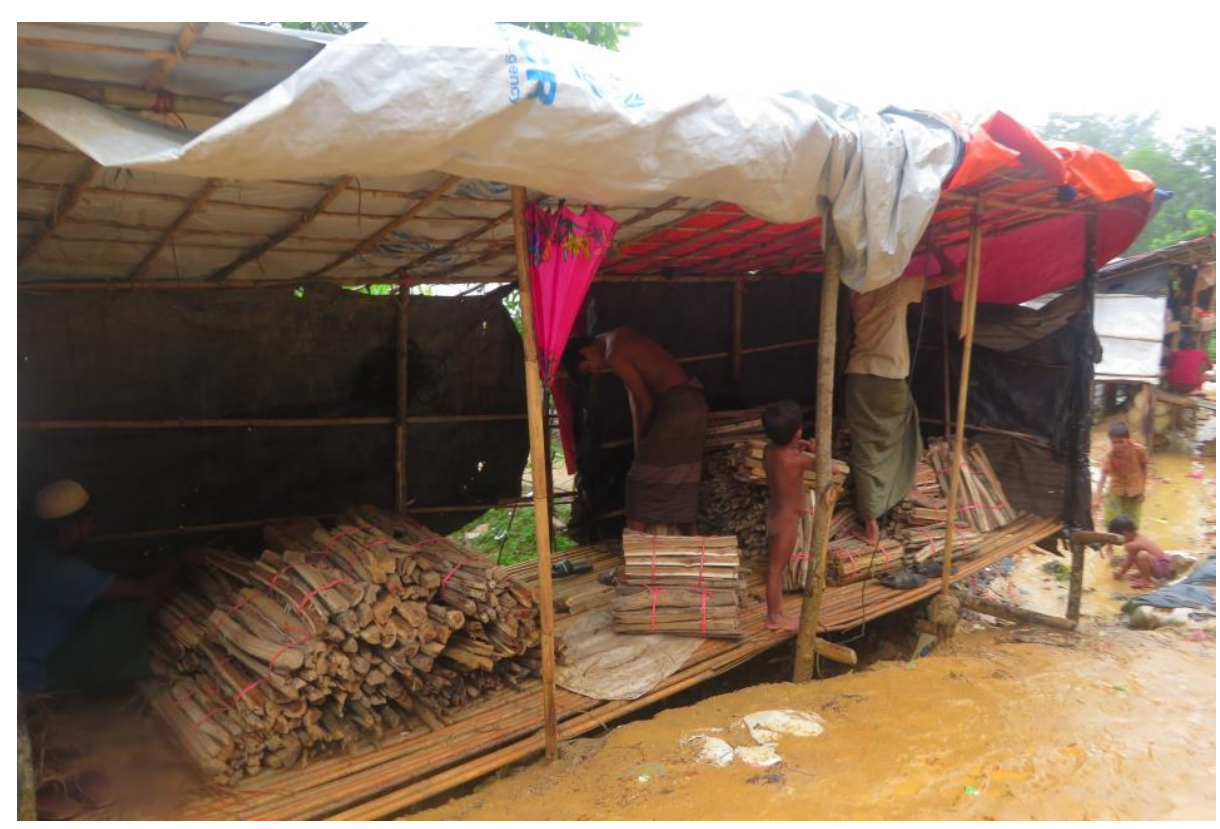

Figure 3. Selling forest resources as fire woods

All the 21 canals and streams in the area became completely polluted. More than 100 tons of disposable garbage in the camps apart from plastics and polythene are collected every month. In addition to local biodiversity, marine resources, acoustic environment and air quality have been degraded at an alarming pace (UN Environment 2018).

However, initially when providing food aid, the lack of any cooking system was overlooked and refugees were not provided with any cooking materials (Huq, 2018). Ultimately, in the Rohingya's quest for cooking fuel, the forest cover in the Rohingya receiving region has reduced in substantial scale (Quader et al. 2020). Increasing pressure on local ecosystem not only affected the wellbeing of local forest resources, but also impacted the quality of life and living for both the host and incoming Rohingya populations. In 2020, in just three months 20,000 Rohingya households needed immediate shelter assistance because of their immediate exposure to windstorms, heavy rainfall, landslides \& soil erosions, and flooding. Majority of the damage occurred during mid-June and early July, when Rohingya in southeast Bangladesh experienced consecutive days of heavy rainfall and windstorm (Site Management Sector Cox's Bazar 2020).

\section{Environmental Responsibility}

Refugees, of course, are not "fumes, nevertheless, certain legal similarities exist between environmental damages and a mass influx of displaced people: both may cross international boundaries from countries of origin; both such crossings are preventable by the countries of origin; both such crossings are not made with the voluntary consent of the receiving states; and both such crossings may impose economic and social burdens upon the receiving states, for which the countries of origin will be responsible" (Lee 1993: 554). Thus, it merits considering an environmental approach to refugees as an inroad towards creating an actionable claim against the sending state for breaching its responsibilities towards a population group under international law.

Interestingly, the discussions before the aforementioned international bodies like the ICJ or the ICC did not include environmental damage either in Myanmar during the violence, or in Bangladesh once the Rohingya 'settled in' after their forced migration from Myanmar. Perceiving the responsibility that has been acknowledged by states towards refugees, especially when their situation of displacement resulted from actual and intentional crimes committed by the state, in the context of environmental damages opens up the possibility for actionable remedies, in accordance with other forms of environmental actions against states. The turn to environmentally based causes of action also can provide actual remedies from the sending state that might even alleviate the situation for the better for both the receiving state and for the refugees that are affected by the actions of the sending state. Further, a turn to environmental justice affords an opportunity for proper enforcement of a decision, at the very least to seize or attach assets of the sending state should they balk at respecting a court decision against them. 
This is an author-produced, peer-reviewed version of this article. The final, definitive version of this document can be found online at Local Environment, published by Taylor \& Francis. Copyright restrictions may apply. doi: 10.1080/13549839.2020.1849078

The crux of the argument in this paper is to contemplate the emerging avenues and legal grounds under international environmental law that might result in holding Myanmar as liable for the environmental damages caused in Bangladesh and to the Rohingya themselves. In this situation, environmental damage serves to create viable avenues of redress for the receiving state and the refugee population found therein given the shifts that have occurred in perceiving state responsibility regarding the environment. This legal responsibility includes the duty to protect and preserve the environment, and the obligation to uphold attendant human rights that are inherently linked with a state's responsibility to provide a stable and suitable environment for people found within its jurisdiction (or for depriving them of same as a result of forcible removal from its jurisdiction).

The United Nations High Commissioner for Refugees (UNHCR) Environmental Guidelines (1996) illustrate the major environmental impacts caused by refugees' or asylum-seekers' influx into receiving states in noting that:

“...refugee activities such as uncontrolled fuel wood collection, poaching, and over-use of limited water supplies, add pressure to ecosystems in many regions, including some unique areas set aside by local governments as parks, reserves or even World Heritage Sites. In the worst case, these activities, if allow to continue, could result in irreversible losses of productivity, the extinction of plant or animal species, the destruction of unique ecosystems, the depletion or long-term pollution of ground water supplies, or a variety of other destructive outcomes." (UNHCR, 1996: 5).

Importantly, when considering environmental damage caused from one state to another, the no harm rule is the rule in play, whereby a state is under a strict obligation not to cause environmental harm in another state (Jervan 2014). This prohibition of transboundary harm is considered to be binding customary international law on all states (Schwabach, n.d). Thus, in a 2018 ICJ case involving Costa Rica and Nicaragua, the ICJ found that Nicaragua was liable to compensate Costa Rica for damages incurred to an environmentally protected wetlands in Costa Rica. The ICJ held that Costa Rica had to be compensated for the recovery of environmental goods that were lost as a result of Nicaragua's canal digging, along with payment for actual damage caused to Costa Rica's environmentally protected areas. They key aspect here was that a direct connection needs to exist between the wrongful act taken by the state and the eventual environmental damage that resulted from that act (Cittadino 2019).

\section{Conclusion}

Mistakenly displaced populations or refugees around the world are often identified both by media and local host residents for causing environmental degradation in receiving areas (Meierotto 2012). However, the popular narrative often misses the reasons behind those environmental degradation or disruption. This paper unpacks that narrative and addresses the importance of including the refugee sending state into the discussion of environmental disruption in refugee receiving state. In the case of state-state responsibility, the no-harm rule is a primary rule that binds all states. In order for Bangladesh to have standing to invoke the no-harm rule, Bangladesh must demonstrate that it is an "injured state" in accordance with Article 42 of the ILC Draft Articles on State Responsibility, a rather clear result for Bangladesh given the aforementioned severe environmental damage and stress that resulted from the huge influx of Rohingya as a result of Myanmar's discriminatory and violent policies against them. Thus, there are strong grounds for Bangladesh to make a claim against Myanmar at the very least to subsidize the great expense borne by the huge refugee influx, and to have Myanmar assist in remedial efforts for the damaged environment.

Similarly, the refugee's rights in question, at least from an environmental basis (as that notion has been emerging in international law) also have been severely violated by Myanmar, at the very least with regard to their right to live a dignified life in their homeland. The Rohingya current state of existence and strive for a modicum of a life with dignity is severely hampered, if not even non-existent at certain times, such that strong grounds exist on the basis of environmental grounds, to find that a causative result of Myanmar's actions has been a serious deprivation of Rohingya's environmental capacities.

\section{References}

Ahmed, S. 2018. "The Rohingya Refugee Crisis: Photos Show Bangladesh Camps Are Vulnerable to Impending Monsoons." NewSecurityBeat-the blog of the Environmental Change and Security Program. https://www.newsecuritybeat.org/2018/03/rohingya-refugee-crisis-photos-show-bangladesh-campsvulnerable-impending-monsoons/ 
This is an author-produced, peer-reviewed version of this article. The final, definitive version of this document can be found online at Local Environment, published by Taylor \& Francis. Copyright restrictions may apply. doi: 10.1080/13549839.2020.1849078

Ahmad, N. 2009. "Refugees: State Responsibility, Country of Origin and Human Rights." Asia Pacific Journal on Human Rights and the Law 10(2): 1-22.

Amnesty International. 2017. Myanmar: Rohingya trapped in dehumanizing apartheid regime. amnesty.org/en/latest/news/2017/11/Myanmar-rohingya-trapped-in-dehumanising-apartheid-regime/

Akhavan, P., M. Bergsmo. 1989. "The Application of the Doctrine of State Responsibility of Refugee Creating States." Nordic Journal of International Law 54: 243-256.

Andjelkovic, S. 2019. Application of the CERD - Case Qatar v. United Arab Emirates. Institute for a Greater Europe. https://www.institutegreatereurope.com/single-post/2019/10/19/Application-of-the-CERD$\%$ E2\% 80\%93-Case-Qatar-v-United-Arab-Emirates.

Arnpriester, N., and L. Bingham. (2019). Case Watch: Ukraine ICJ Ruling Strengthens Protections against Discriminatory Use of Citizenship Law Open Society Justice Initiative. https://www.justiceinitiative.org/voices/case-watch-ukraine-icj-ruling-strengthens-protections-againstdiscriminatory-use-of-citizenship-law

Barron, L. 2020. U.N.'s Top Court Orders Myanmar to Take All Measures to Prevent Genocide Against Rohingya. time.com/5770080/Myanmar-rohingya-genocide-un-court/

BDNews24.com. 2018. Bangladesh gives opinion to International Criminal Court on Myanmar's trial over Rohingya. https://bdnews24.com/bangladesh/2018/06/07/bangladesh-gives-opinion-to-internationalcriminal-court-on-myanmars-trial-over-rohingya

Bhuiyan, H.K. 2019. Rohingya genocide case against Myanmar: West's failure to support the Gambia surprising, if not shocking. The Dhaka Tribune (29 December, 2019). https://www.dhakatribune.com/bangladesh/rohingya-crisis/2019/12/29/rohingya-genocide-case-againstmyanmar-west-s-failure-to-support-the-gambia-surprising-if-not-shocking

Bowcott, O. 2019. Gambia files Rohingya genocide case against Myanmar at UN court. The Guardian (Mon 11 Nov 2019). https://www.theguardian.com/world/2019/nov/11/gambia-rohingya-genocide-myanmar-un-court

Beyani, C. 1995. "State Responsibility for the Prevention and Resolution of Forced Population Displacements in International Law.” International Journal of Refugee Law 7 (Special Issue): 130-147.

Cittadino, F. 2019. Science novit curia? Damage evaluation methods and the role of experts in the Costa Rica v Nicaragua case Federica. http://www.qil-qdi.org/scientia-novit-curia-damage-evaluation-methods-and-therole-of-experts-in-the-costa-rica-v-nicaragua-case/

Council on Foreign Relations. 2018. Rohingya Crisis in Myanmar. https://www.cfr.org/interactives/global-conflicttracker\#!/conflict/rohingya-crisis-in-myanmar

Curfman, G. 2018. ICC Jurisdiction and the Rohingya Crisis in Myanmar. https://www.justsecurity.org/50793/iccjurisdiction-rohingya-crisis-myanmar/

Freedman, J. 2019. Grand Challenges: Refugees and Conflict Frontiers in Human Dynamics. https://www.frontiersin.org/articles/10.3389/fhumd.2019.00001/full

GFDRR. 2018. Rohingya Crisis 2017-2018 Draft Rapid Impact, Vulnerability and Needs Assessment: Executive Summary. Spring 2018 Meeting of the GFDRR Consultative Group. Washington, D.C.: Global Facility for Disaster Reduction and Recovery.

Hassan, M.M, A.C. Smith, K. Walker, M.K. Rahman, and J. Southworth. 2018. "Rohingya Refugee Crisis and Forest Cover Change in Teknaf, Bangladesh." Remote Sensing 10(5): 689. https://doi.org/10.3390/rs10050689

Howland, T. 2007. "The Multi-State Responsibility for Extraterritorial Violations of Economic, Social and Cultural Rights." Denver Journal of International Law \& Policy 35: 389-411.

Huq, S. (2018). Tackling the environmental challenges in Cox’s Bazar. The Daily Star (Feb 07, 2018). https://www.thedailystar.net/opinion/politics-climate-change/tackling-the-environmental-challenges-coxsbazar-1530940

ICJ. 2020. Application of the Convention on the Prevention and Punishment of the Crime of Genocide (The Gambia v. Myanmar). Accessed 2 August 2020. icj-cij.org/en/case/178

Jervan, M. 2014. "The Prohibition of Transboundary Environmental Harm. An Analysis of the Contribution of the International Court of Justice to the Development of the No-harm Rule." PluriCourts Research Paper No. 14-17. https://ssrn.com/abstract=2486421

Kamruzzaman, M. 2020. Argentinian court decision brings hope for Rohingya, Anadolu Agency. Accessed 02 June 2020. https://www.aa.com.tr/en/americas/argentinian-court-decision-brings-hope-forrohingya/1861967?fbclid=IwAR0afK-cf-muhLeML4ZCattDOxWDSOHF0QWgiSOoyO_SHjx4S4eGpYghR8. 
This is an author-produced, peer-reviewed version of this article. The final, definitive version of this document can be found online at Local Environment, published by Taylor \& Francis. Copyright restrictions may apply. doi: 10.1080/13549839.2020.1849078

Lee, L. T. 1986. "The Right to Compensation: Refugees and Countries of Asylum.” The American Journal of International Law 80 (3): 532-567.

Lee, L. T. 1993. "The Declaration of Principles of International Law on Compensation to Refugees: Its Significance and Implications." Journal of Refugee Studies 6(1): 65-70.

Maruf, B.U. (2018). Civil Society and Experts express concern on ecological damages and urge for quick repatriation or decongestion or redistribution of Rohingya Refugees. Dhaka, 4th June 2018, Press Release. Coastal Association for Social Transformation Trust. Dhaka. https://www.thefinancetoday.net/article/weather-environment/2525/Environment-Recovery-Fund-is-urgedto-Save-Natural-Resources-of-Coxs-Bazar

McCue, G.S. 1993. "Environmental Refugees: Applying International Environmental Law to Involuntary Migration." Georgetown International Environmental Law Review 6: 151-190.

Meierotto, L.M. 2012. "The Blame Game on the Border: Perceptions of Environmental Degradation on the United States-Mexico Border.” Human Organization 71(1): 11-21.

Nollkaemper, A. 2020. "Systemic Effects of International Responsibility for International Crimes." Santa Clara Journal of International Law 8(1): 313-352.

Quader, M.A., H. Dey, M.A. Malak, A.M. Sajib. 2020. Rohingya refugee flooding and changes of the physical and social landscape in Ukhiya, Bangladesh. Environment, Development and Sustainability. https://doi.org/10.1007/s10668-020-00792-0

Schwabach, A. (n.d.). Transboundary Environmental Harm and State Responsibility: Customary International Law. Encyclopedia of Life Support Systems. https://www.eolss.net/Sample-Chapters/C14/E1-36-02-02.pdf

Singh, P-P. 2020. World Court Rules Against Myanmar on Rohingya: International Court of Justice Unanimously Orders Measures to Prevent Genocide. Human Rights Watch (January 23, 2020). hrw.org/news/2020/01/23/world-court-rules-against-myanmar-rohingya

Site Management Sector Cox's Bazar. 2020. Impact of the Monsoon \& COVID-19 Containment Measures: Shelter and infrastructure damage in the Rohingya refugee camps. https://reliefweb.int/report/bangladesh/impactmonsoon-covid-19-containment-measures-shelter-and-infrastructure-damage

Trail Smelter (U.S. v. Can.), 3 R. Int'l Arb. Awards 1905 (1938 \& 1941) (Letter of the Minister of the United States of America at Ottawa to the Secretary of State for External Affairs of the Dominion of Canada, Jan. 30, 1934).

UN. 2017. Darker and more dangerous: High Commissioner updates the Human Rights Council on human rights issues in 40 countries. Human Rights Council 36th session. New York: The United Nations.

UN. 2018. JRP (Joint Response Plan) for Rohingya Humanitarian Crisis. https://reliefweb.int/sites/reliefweb.int/files/resources/JRP\%20for\%20Rohingya\%20Humanitarian\%20Crisi s\%20-\%20FOR\%20DISTRIBUTION.PDF

UN Environment. 2018. A precarious environment for the Rohingya refugees. unenvironment.org/news-andstories/story/precarious-environment-rohingya-refugees

UNHCR. 1996. The United Nations High Commissioner for Refugees (UNHCR) Environmental Guidelines. Geneva: The United Nations High Commissioner for Refugees.

UNHCR 2020. Global Trends: Forced Displacement in 2019. Geneva: The United Nations High Commissioner for Refugees.

UNDP Bangladesh and UN WOMEN Bangladesh 2018. Report on Environmental Impact of Rohingya Influx. Dhaka, Bangladesh.

United Nations Human Rights Office of the High Commissioner. 2017. Treaty CESCR-International Covenant on Economic Social and Cultural Rights (Signature Date: 28 Sept 2015; Ratification Date, Accession, Succession Date: 06 Oct 2017). https://tbinternet.ohchr.org/_layouts/15/TreatyBodyExternal/Treaty.aspx?CountryID=119\&Lang=EN

Vermeylen, S. 2019. "Special issue: environmental justice and epistemic violence." Local Environment 24 (2): 8993. DOI: $10.1080 / 13549839.2018 .1561658$

World Bank. 2011. World Development Report 2011: Conflict, Security, and Development. Washington, D.C.: World Bank. 